\title{
Does Hungarian have a case system?
}

\author{
Andrew Spencer \\ University of Essex
}

\begin{abstract}
I argue that case markers in Hungarian are best thought of as 'fused postpositions'. There is no need to set up a separate syntactic or morphological [Case] attribute as such. Rather, we just need a morphological principle stating that nominals (including pronouns) have a special form, the traditional case form. In this respect Hungarian is crucially different from languages such as Latin (which requires both a morphological and a syntactic [Case] feature) or Finnish (which requires at least a syntactic [Case] feature). I discuss certain typological issues arising from this analysis, arguing that when grammarians refer to Hungarian 'cases', they are really referring to a rather more general notion of 'canonical grammatical function markers on dependents'.
\end{abstract}

\section{Introduction ${ }^{1}$}

The notion of 'case' is one that is often taken as a given by linguists but, as Comrie (1986) demonstrated, concisely and clearly, the notion is far from straightforward and the traditional understanding actually encompasses a number of distinct, though interrelated, phenomena. Comrie (1986) argues that we need to distinguish a morphological notion of case, the 'case forms' of a lexeme, from a functional notion, the 'case' that a noun phrase is 'in' in a given construction. ${ }^{2}$ The

1. Parts of this paper have been presented in talks at the universities of Paris VII (Alliance funded research exchange), Surrey (ESRC-funded Grammatical Features project), Essex, York (York Essex Morphology Meeting 3) and the 12th International Morphology Meeting, Budapest. I am grateful to the audiences at those talks for useful comments, and especially to Bob Borsley, Sonja Eisenbeiss, Claudia Felser, Jean-Pierre König, and Anna Zribi-Hertz. Thanks to Danièle Goddard for originally directing me to the work of Denis Creissels and especially to Edith Moravcsik for very detailed and helpful comments. Default disclaimers apply.

2. Sadler \& Spencer (2001) argue for a generalized version of this distinction, since it is frequently the case that a property such as 'tense,' 'voice' or 'definiteness' is realized synthetically, by a specific form of a lexeme, in some contexts, and by some kind of periphrastic construction in other contexts. See Spencer (2003) for further discussion of the point that the syntactic notion of 'case' is really a property of noun phrases, while the morphological property is (typically/canonically) a property of word forms. 
basic reason for this is simple: we often find that the 'wrong' morphological form can realize a syntactically defined case function, in other words we have form: function mismatches.

As Comrie (1986: 89) points out, in a thoroughly agglutinating language such as Turkish ' $(\ldots\rangle$ the traditional cases (nominative, accusative, genitive, dative, locative, ablative) can just as readily be identified by their suffixes $\langle\ldots\rangle\rangle$, as, indeed, is done in the Dravidian native descriptive tradition. His main arguments rest on inflectional languages such as Russian and Latvian, where there is a clear need for a morphological case feature in order to generalize across distinct forms in different inflectional classes, grammatical number forms and so on. He shows that we need to look to the formal distinctions made in the morphology of the language, the functional/distributional distinctions found in the syntax, and establish a mapping between form: function, which will often as not be a many: one relation. This may even be true of languages such as Turkish, where it is only a definite/specific direct object that gets marked with the accusative suffix, while an indefinite/non-specific object remains unmarked (and hence in the 'nominative' case?).

The point about Turkish is crucial to my subsequent discussion of Hungarian so I will expand on it a little here. In an inflecting language such as Russian forms of nominal words reflect various syntactic properties and functions, so that there is a special form for subjects, objects, possessors, complements to prepositions and so on. These are the traditional cases, which in Russian include nominative, accusative, genitive, prepositional. However, different classes of nominals may realize these cases by means of entirely different forms, and, moreover, for a given lexeme one and the same case may assume a different form in the singular and the plural. The genitive singular of kniga 'book' is knigi and the genitive plural is knig, while the genitive singular/plural of bloknot 'notepad' are bloknota/bloknotov. Yet in terms of syntactic privileges of occurrence these are all just genitive case forms. To capture this fact the grammar of Russian therefore requires an abstact attribute or feature [Case] with values such as [Case: genitive]. This much is obvious. Equally obvious ought to be the fact that corresponding nouns in, say, French lack a genitive of this sort, or indeed any case. The 'genitive' function in French is realized by the preposition $d e$. To state the distribution of de we do not need to appeal to an attribute-value pair [Case: genitive]. Instead, the grammar requires statements of the form 'in such-and-such a syntactic environment make the NP the complement of the preposition de. Similarly, there is no need to label English prepositions such as of, to, with, from, etc. as 'genitive', 'dative', 'instrumental', 'ablative' cases. The fact that there is no need for a [Case] attribute in Frencha nd English doesn't prevent grammarians from talking about 'case forms' in these languages, but that is either an abuse of terminology or a mis-analysis. 
The conceptually puzzling situations arise in languages which express 'case' meanings and functions by dedicated forms of the nominal which are identical across lexemes. Thus, in Turkish the word kitap 'book' has the forms kitap-in 'of a book' and kitaplar-in 'of books'. The nominals seem to bear morphological case suffixes and this seems to warrant setting up a [Case] attribute, with a value [Case: genitive], but Comrie's observations cause us to question this and Beard (1995) explicitly argues that such an attribute is extraneous in a formal grammar. Statements of distribution of such 'cases' can take the form 'in such-and-such a syntactic environment select the -In form of the head noun of the noun phrase. By appealing to the notion 'the -In form of a nominal' we obviate the need for a (morphological) [Case] attribute. Of course, there may still be need for a [Case] attribute in the syntax. To a large extent Finnish nominals inflect for case in an entirely agglutinating manner, just like Turkish (or Hungarian). However, Finnish adjectives agree in case with their head nouns. This fact cannot be stated without appeal to a [Case] attribute in the syntax, otherwise the agreement facts would have to be couched as a dozen unrelated facts about each separate case form. Thus, a language such as Finnish does have a case system, though arguably only in the syntactic sense.

When we come to ask whether a language has a case system, therefore, we must really ask two sets of conceptually independent questions: (i) is there a need for a [Case] attribute in the morphology to capture generalizations purely about forms? (ii) is there a need for a [Case] attribute in the syntax to capture generalizations about the parallel distributions of sets of distinct forms? (This is what Spencer and Otoguro 2005, refer to as 'Beard's Criterion'). I argue that for Hungarian the answer to both questions has to be 'no'.

The chapter is organized as follows. In $\$ 2$ I lay out the essentials of the traditional case system of Hungarian, including the postpositions, whose position in the system will prove rather ambivalent. In \$3 I lay out the grammatical properties of the case forms, together with relevant allomorphic variation in suffixes and in stems. This establishes that Hungarian cases are at least affixes (as opposed to clitics, say). However, we find no evidence of a syntactic case attribute. In $\$ 4$ we examine the postpositions and find that they share certain features with case endings and certain features with fully-fledged nouns. The central question is broached in $\$ 5$, where I argue that there is no (strong) sense in which Hungarian can be said to have a case system. ${ }^{3}$ Rather, Hungarian cases suffixes are special fused portmanteau affixal post positions, and no more deserve to be called 'cases' than prepositions such as English 'of'. However, these forms realize cross-linguistically identifiable functions in the form of canonical grammatical function markers on dependents.

3. I thus arrive at different conclusions from Borin (1986). 
Both the morphological forms ('fused postpositions') and the canonical GF markers on dependents can be called 'case', but only in a weak and potentially misleading sense. I contrast Hungarian with the Samoyedic language Selkup, which has a similar array of suffixal 'cases', but additionally a suffix occupying the 'case' slot which creates similitudinal adjectives, with no case-like function at all. Finally, I draw summary conclusions.

\section{Basic Hungarian facts}

\subsection{The traditional case system}

In the descriptive sections I will use the term 'case' in its traditional sense, even though I will be arguing that the suffixes themselves are not case markers proper.

The case suffixes are added to lexemes which can function as nouns, including adjectives and numerals used as nouns. They are not, however, added to infinitive forms of the verb. The case suffixes follow other inflections, namely plural and possessor agreement. With one minor exception the suffixes show no clitic-like (phrasal affix) properties (for example, there are no 'suspended affixation' effects).

The inventory of cases is a matter for dispute and ranges from 17 (including the zero-marked nominative) to 28, with varying estimates between (Moravcsik 2003a: 117, for instance, has 22 cases). Kiefer (1987; see also Kiefer 2000: 580) provides one of the rare descriptions of the system which actually provides linguistic arguments in favour of a particular enumeration. He shows that there are eighteen case-marked forms (including the nominative) that behave specifically like nouns as opposed to adverbials. These are the case suffixes that can be attached to nouns already inflected for number and/or possessor. The resulting noun form can be used as the argument of a noun-taking predicate. I will follow Kiefer in considering just these eighteen forms as cases, though it's of theoretical interest that other forms have been traditionally included in the list.

Some cases are essentially grammatical in function (nominative, accusative, dative):

(1) Hungarian case forms of ember 'person'

nominative ember

accusative ember- $t$

dative ember-nek

The nine cases in (2) have primarily local/spatial meanings cumulating 'orientation' with 'position/direction', essive (at rest), allative (motion to), ablative (motion from) (adapted from Comrie \& Polinsky 1998: 107; Kenesei, Vágo \& Fenyvesi 1998: 235): 
(2) Hungarian local cases

a. 'in' orientation

essive inessive ember-ben 'in'

allative illative ember-be 'into'

ablative elative ember-böl 'from inside of'

b. 'on' orientation

essive superessive ember-en 'on'

allative sublative ember-re 'onto'

ablative delative ember-ról 'from the surface of'

c. 'at' orientation

essive adessive ember-nél 'at'

allative allative ember-hez 'towards'

ablative ablative ember-töl 'from (near)'

The remaining six have various 'adverbial' meanings:

(3) Hungarian semantic cases (with basic allomorph and approximate gloss; casenames following Kenesei et al. 1998: 1924)

$\begin{array}{lll}\text { instrumental } & \text { ember-rel } & \text { 'with' } \\ \text { causal-final } & \begin{array}{l}\text { ember-ért } \\ \text { translative }\end{array} & \text { 'as' } \\ \text { ember-ré } & \text { '(change) into' } \\ \text { terminative } & \text { ember-ig } & \text { 'up to' } \\ \text { essive-formal } & \begin{array}{l}\text { ember-ként } \\ \text { emsive }\end{array} & \text { 'in the capacity of' } \\ \text { emberl } & \text { 'in the capacity of' }\end{array}$

All the endings except -ért, -ig, -ként show allomorphy. Non-labial vowels alternate between $a \sim e$ in back/front vowel harmony contexts, while allative -hoz/hez/höz and superessive $-n /$ on/en/ön show limited labial harmony as well. The instrumental and translative suffixes - val and -vá also undergo consonant assimilation as seen in the forms ember-rel, ember-ré. The accusative triggers stem allomorphy, to be discussed below. It's worth mentioning that a number of the 'adverbial' suffixes not counted by Kiefer as cases also exhibit allomorphy and vowel harmony, for instance, the so-called comitative -stul, -stül, -ostul, -astul, -estül, -östül. Hungarian has no inflectional classes, so the same endings are used for all lexemes (but see below for case forms of pronouns).

4. Hungarian grammars use Latinized case names, but in the literature generally, case terminology appears not to be fixed. Kiefer (2000: 580) has 'translativus-factivus' for 'translative', 'formativus' for 'essive-formal' and 'superessivus' for 'essive.' However, 'superessivus' is also used for the local superessive case. Tompa (1985) has 'Translativ-Faktitiv' for 'translative', but 'EssivFormal' for 'essive-formal'. However, for 'essive' he has 'Essiv-Modal'.

5. In Kiefer (2000: 580) this form is unfortunately misprinted as embert-ért. 


\subsection{Postpositions}

Hungarian is rich in postpositions. True postpositions take the nominative form of the dependent noun (Kenesei et al. 1998: 337): mögött 'behind' a ház mögött 'behind the house. Traditional descriptions include as postpositions adverbials which take a case-marked form of the noun (Kenesei et al. 1998: 338), such as kiviul 'beside': $a$ ház-on kívül lit. 'the house-superessive beside'. However, Creissels (2003) argues convincingly that these are best not treated as true postpositions, but rather have the syntax of nouns. For instance, the kívül-type postposition can come either side of its complement, kívül a házon, which is impossible for the mögött-type. Secondly, it is possible to separate the kivül-type from its complement with a word such as pontosan 'just', but this too is impossible with the mögött-type, which must remain in tight juncture with its complement noun. Thirdly, when the complement of a true postposition such as mögött is modified by a demonstrative the postposition has to be repeated after that demonstrative, as in (4) (see also Kenesei et al. 1998: 278):

(4) e mögött a ház mögött

THIS behind THE house behind

'behind this house'

However, a complement to a kívül-type postposition does not permit such doubling of the postposition after the demonstrative; instead, the demonstrative assumes the case suffix of complement noun, just as in any other noun phrase type:

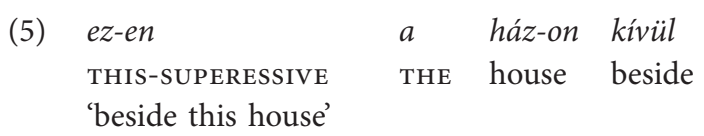

It is only the true postpositions such as mögött that show interesting parallels with the case suffixes, so in future I shall be referring exclusively to such elements when I speak of 'postpositions'.

Some of the spatial postpositions have distinct orientation forms, mirroring the three-way division of spatial cases essive, allative, ablative. Some common examples are shown in (6):

(6) Spatial distinctions in postpositions

$\begin{array}{llll} & \text { essive } & \text { allative } & \text { ablative } \\ \text { under } & \text { alatt } & \text { alá } & \text { alól } \\ \text { over } & \text { fölött } & \text { fölé } & \text { fölül } \\ \text { in front of } & \text { elött } & \text { elé } & \text { elöl } \\ \text { behind } & \text { mögött } & \text { mögé } & \text { mögül } \\ \text { near } & \text { mellett } & \text { mellé } & \text { mellöl } \\ \text { between } & \text { között } & \text { közé } & \text { közül }\end{array}$




\section{Grammatical properties of cases}

\subsection{Morphosyntax}

The cases fail to trigger any processes that would require appeal to a syntactic case attribute, in particular, there is no case agreement/concord or multiple marking of any kind within the noun phrase. There are two apparent exceptions to this statement. First, appositional modifiers (including numerals), separated from their head noun, take the same nominal inflections as the nouns to which they relate (Tompa 1985: 185f).
(7) Az üzem-ben, azúj-ban, megindult a munka the enterprise-INESS the new-INEss started.up the work 'Work has begin in the enterprise, the new one'

In $(8,9)$ we see that possessive form nouns and pronouns take case endings in the same way as adjectives:

(8) Még nem voltam az iskolá-ban a fia-m-é-ban still not I.was the school-Iness the son-my-his-INess 'I still haven't been to the school, my son's, that is'

(9) Felépitjük a háza-t, a magunké-t we.build the house-ACC the ours-ACC 'We are building the house, our own one'

In these appositional constructions we don't have agreement within the NP, because the modifiers don't form a constituent with their heads.

The second type of exception is found with the demonstratives $e z$ 'this', $a z$ 'that' and other demonstratives based on these (emez/amaz 'this/that other', ugyanezl ugyanaz 'this/that same'). The demonstratives obligatorily take number/case inflections (though not possess inflections), apparently agreeing with the head noun (a list of forms is given in Kenesei et al. 1998: 277-8). However, the consensus seems to be that the demonstratives are in apposition (Moravcsik 2003b: 448; Tompa 1985: 181). A syntactic indication of this is that the demonstratives invariably appear before a definite article, which otherwise seems to mark the left edge of the NP:
a. ez-ek-ben a háza-k-ban
this-PL-INESS the house-PL-INESS
'in these houses'
b. *az ezekben házakban

One conceptual reason that could be cited for not treating the doubling as agreement, at least where case suffixes are concerned, is that some of the case suffixes don't trigger doubling, namely, locative, iterative, comitative, essive, distributive, 
multiplicative, modal, modal-essive (Kenesei et al. 1998: 277). Now, of these only the essive is universally accepted as a case suffix (and is the only one which I have included as a bona fide instance). However, the conceptual problem remains. Some of the traditional cases left out of the list of eighteen do trigger doubling with demonstratives, including the temporal-kor, the formal -képpen 'as, in the capacity of'). Moreover, the majority of the true postpositions are also usually repeated after the demonstratives, as we saw in (4) above. Such doubling is even (optionally) possible with 'fake' postpositions, such as kiviul + sUPERESSIVE 'beside', which are really nouns taking a case-marked complement, but then the demonstrative assumes the case form of the complement: ${ }^{6}$

$\begin{array}{lll}\text { ez-en } & \text { kívül a könyv-ön } & \text { kívül } \\ \text { this-SUPERESSIVE } & \text { beside the book-superessive } & \text { beside }\end{array}$

'beside this book' (Moravcsik 2003a: 208)

A final distinction between true postpositions and those taking case-marked complements is that the final $-z$ of $e z / a z$ is 'deleted' before true postpositions, as in (12) where ez 'this' appears as $e$ (Kenesei et al. 1998: 278; see also Moravcsik 2003a: 208):

A kulcs e mellett a könyv mellett van
the key this near the book near is
'The key is near this book'

I have taken it for granted that the case endings are bona fide affixes, rather than, say, clitics. This is justified by a number of properties. First, the accusative affix triggers idiosyncratic allomorphy on the stem (see below), a characteristic of affixes not of clitics. Second, the suffixes lack almost all of the standard clitic properties. They show no promiscuous attachment (if we grant that numerals, adjectives and other modifiers with null heads are functionally nouns) and they show no signs of the 'suspended affixation' phenomenon characteristic of, say, Turkish, in which a single suffix takes scope over a coordinated phrase. Thus, corresponding to a kert-benés a park-ban 'in the garden and (in) the park' we have no constructions such as *[a kert-és a park]-ban.

However, there is one construction in which the cases seem to behave more like edge inflections or phrasal affixes than like bona fide stem-based affixes. The

6. From Moravcsik's (2003a: 208f) discussion it would appear that demonstratives agree with the nouns even when the repeated element is a 'fake' postposition. However, she points out that this conclusion only holds if we regard the demonstrative as part of the NP constituent, and not in apposition. Relevant here are her three arguments in favour of treating the demonstrative as appositional (Moravcsik 2003b: 448). Perhaps the conclusion to draw from this is that Hungarian has an incipient, but as yet highly non-canonical system of 'agreement', which is therefore better thought of as multiple marking. In any event it is hardly sufficient to warrant setting up an independent syntactic [Case] attribute. 
Hungarian pseudo-partititive construction (see Selkirk 1977, for discussion of the corresponding English construction) which translates 'a box of apples', 'a pint of milk' is formed by taking a measure noun (phrase) and following it with the semantic head, literally 'a box apple', 'a pint milk'. The components of the phrase can be elaborated by modifiers ('a large box of red apples'), as in (13):

(13) az a három nagy üveg tokaji bor that the three large bottle Tokaj wine 'those large bottles of Tokai wine'

When we overtly case-mark the whole expression, the case-marker occurs not on üveg 'bottle', but on the final word of the phrase, bor 'wine'. This is surprising if we assume that üveg 'bottle' is the syntactic head of the phrase rather than bor 'wine'.
a. Kérem az-t a három nagy üveg tokaji bor-t
I.ask.for that-ACC the three large bottle Tokaj wine-ACC
'Those three large bottles of Tokaj wine, please'
b. ${ }^{*}$ Kérem azt a három nagy üveg-et tokaji bor I.ask.for that-ACC the three large bottle-ACC Tokaj wine

I have not found in the literature any detailed formal discussion of this phenomenon or its implications. The fact that the demonstrative takes the accusative marker shows that the accusative suffix on bort in (14a) is somehow marking üveg as 'being in the accusative', though this represents a significant departure from the default morphology-to-syntax relation. ${ }^{7}$

\subsection{Allomorphy}

With the exception of $z$-assimilation with demonstratives and the assimilation shown by $v$-initial suffixes, the case markers generally fail to trigger or undergo idiosyncratic allomorphy. The principal exception is the accusative suffix -t. Accusative suffixes may trigger idiosyncratic (i.e., unpredictable) stem allomorphy. Stems ending in a consonant may acquire a vowel extension before certain consonant-initial affixes. For instance, a consonant-final noun stem generally

7. Preliminary investigations suggest that the edge marking phenomenon may affect more than just the case system. If in examples such as (14a) we wish to talk about bottles, or about your bottle(s) the plural and/or possessor agreement markers, too, appear as edge markers, on bor 'wine' not on üveg 'bottle' (I am grateful to Edith Moravcsik for discussion of the relevant examples). Clearly, rather more is going on here, but this will have to be the subject of further research. 
takes a 'linking vowel' -o(ö)/e before the accusative suffix (and before the plural and possessive suffixes):
a. város város-o-k 'town'
b. tör tör-ö-k dagger
c. egyetem egyetem-e-k 'university'

Adjectives take case suffixes when they are converted to nouns or when they modify a null head. Consonant-final adjectives functioning as nouns tend to take the linker $-a / e$, not the -o/e linker associated with true nouns. Tompa (1985: 44) cites examples including akadémikus 'academic', which has the plural form akadémikus-o- $k$ in the nominal meaning 'members of the Academy' but akadémikus- $a-k$ in the converted adjective function meaning 'things which are academic, theoretical'. But these are at best strong tendencies and there are exceptions in both directions. The noun ház 'house' takes the linker - $a$-, ház-a-k, while the adjective nagy 'large' takes -o-, nagy-o-k.

As Creissels (2003) points out, the choice of linker for all the suffixes that require one is generally determined by the stem. Thus, irregular nouns and adjectives such as ház, nagy take the 'wrong' linker for possessive and accusative forms as well as for the plural:

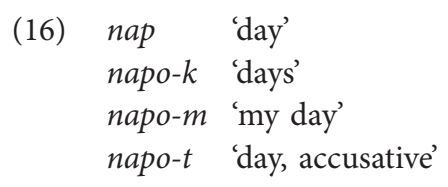

but
ház 'house'
háza-k 'houses'
háza-m 'my house'
háza-t 'house, accusative'

Some nouns undergo other types of stem allomorphy (Kenesei et al. 1998: 194; Moravcsik 2003a: 125-126):

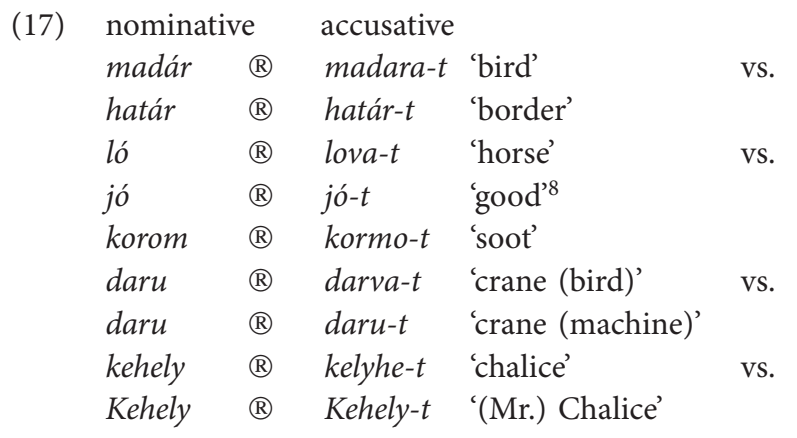

8. As in jót tesz valakinek 'to do somebody good' and various other idioms. 
In this respect the accusative patterns with the plural and possessive affixes (see the paradigms in Kenesei et al. 1998: 194).

Complicating the picture somewhat is the fact that plural and possessive suffixes themselves determine the linking vowel for the following suffix. In both cases the suffix selects the - $a$ back harmony variant, even with (regular) nouns and (irregular) adjectives whose stems select the - $o$ vowel:

$$
\begin{array}{ll}
n a p-o-k-a-t & \text { 'days, accusative' } \\
n a g y-o-k-a-t & \text { 'large ones, accusative' }
\end{array}
$$

However, this fact is somewhat obscured in the traditional analysis of the accusative, which takes these as alternations in the shape of the affix, not the stem. Thus, traditionally we see segmentations in which the linking vowel forms part of the suffix: nap-ok-at, nagy-ok-at etc. (See, for instance, the extended defence of Carstairs' (1987) 'Peripherality Constraint', in Moravcsik 2003a: 219ff, which hinges on the traditional segmentation of the affixes, as set out in Moravcsik 2003a: 116, 118).

Finally, there is an unusual instance of affix allomorphy with 1st/2nd person possessed forms, in which the accusative marker may optionally be zero:

$$
\begin{aligned}
& \text { a. Látom a ház-am-at } \\
& \text { I.see the house-my-ACC } \\
& \text { b. Látom a ház-am } \\
& \text { I.see the house-my } \\
& \text { 'I see my house' }
\end{aligned}
$$

The conclusion from these data is that suffixes select specific allomorphs of their stems (including the linker vowel), and that suffixes themselves have allomorphs selected by immediately following suffixes (for instance, the plural suffix takes the $-a$ - linker when followed by the accusative suffix, even with nouns that normally select the - $o$ - linker with the accusative; see (18) above). One interesting consequence of this analysis is that there is no case suffix allomorphy save for vowel harmony and the assimilatory allomorphy of -val/vel, -vá/vé. In particular, there is no cumulation of case with any other morphosyntactic property. In this respect, the case suffixes, even the accusative, are morphophonologically more like clitics than affixes (though triggering idiosyncratic allomorphy on a stem is a canonical property of affixes, so one can't take this analogy particularly far). I discuss the question of case marking and pronouns below.

\section{Postpositions and cases}

The cases are all fairly recent grammaticalizations from postpositions, and so it shouldn't be surprising to find that cases and postpositions share a number of 
important characteristics. In addition, postpositions are generally derived historically from nouns, and in some respects the postpositions behave as though they were still nouns. What is less expected of a case system is that the case suffixes occasionally behave like nouns, too.

\subsection{Postpositions - similarities to nouns}

Postpositions are fully fledged words with their own stress (and indeed they are usually polysyllabic). Morphosyntactically they resemble nouns in that they take case/possessor suffixes themselves:

$$
\begin{aligned}
& \text { (20) a. a ház mellett } \\
& \text { the house next.to } \\
& \text { b. mellett-e a ház } \\
& \text { next.to-3sg the house } \\
& \text { 'next to the house' } \\
& \text { c. a ház mögött-röl } \\
& \text { the house behind-DEL } \\
& \text { 'from behind the house' }
\end{aligned}
$$

(Creissels 2003)

Postpositions can receive the $-i$ adjectivizer suffix, normally reserved for (the base form of) a noun. Case-marked nouns behave like canonical inflected forms in not accepting this derivational suffix (Moravcsik 2003a: 178f):

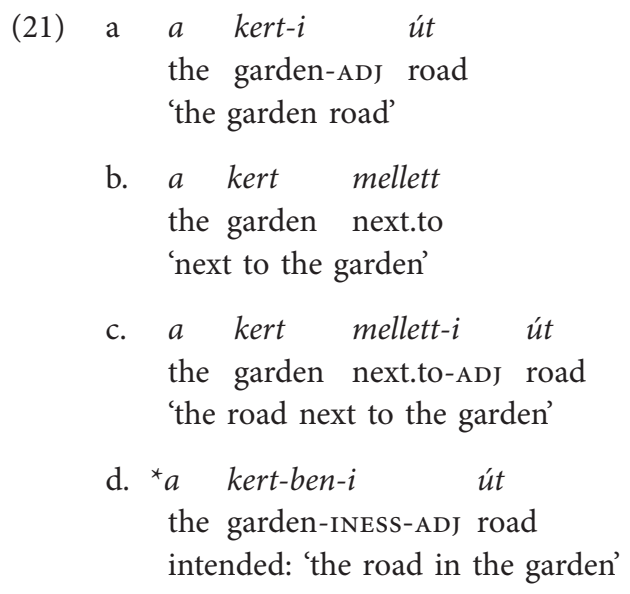

\subsection{Postpositions - similarities to cases}

The true postpositions share a number of characteristics with case suffixes. We have already seen the striking similarities with respect to 'agreement' of the demonstratives $e z / a z$. In addition, the true postpositions take a non-case marked 
(bare, nominative) form of noun complement. Third, they cannot be separated from their noun complement. This is seen in (22):

$$
\begin{aligned}
& \text { a. pontosan János mellett } \\
& \text { just János next:to } \\
& \text { 'just next to János' } \\
& \text { b. *János pontosan mellett } \\
& \text { János just next.to }
\end{aligned}
$$

\subsection{Cases - similarities to nouns}

Perhaps less expectedly, cases suffixes themselves share an important noun-like property with postpositions. Personal pronouns do not have their own case forms. In order to express a 'case feature' such as [Case: Dative] on a pronoun we take a dedicated nominal stem which corresponds to the case marker and inflect it for possessor agreement. The nominal stem is sometimes identical to a case suffix allomorph, but usually it shows partial or total suppletion (Moravcsik 2003a: 161). The system is described by Kenesei et al. (1998: 270f). Examples of pronominal case forms are shown in (23):

(23) a. -nak/nek 'dative', 'to me' etc.

$$
\begin{array}{lll} 
& \text { singular plural } \\
\text { 1st } & \text { nek-em } & \text { nek-ünk } \\
\text { 2nd } & \text { nek-ed } & \text { nek-tek } \\
\text { 3rd } & \text { nek-i } & \text { nek-ik }
\end{array}
$$

b. -ban/ben 'inessive', 'in me' etc.

singular plural

1 st benn-e-m benn-ünk

2nd benn-e-d benn-e-tek

3rd benn-e benn-ïk

c. -hoz/hez/höz 'allative', 'towards me' etc.

singular plural

1st hozz-á-m hozz-á-nk

2nd hozz-á-d hozz-á-tok

3rd hozz-á hozz-á-juk

d. $\quad-(o) n /(e) n$ 'superessive', 'on top of me', etc. singular plural

1st rajt-a-m rajt-unk

2nd rajt-a-d rajt-a-tok

3rd rajt-a rajt-uk

The personal pronouns do not have forms for all of the eighteen uncontroversial cases; the lack the translative, terminative, essive-formal, and essive. 
The accusative involves a greater degree of stem allomorphy, but essentially follows the same pattern, at least for non-3rd person forms (3rd person pronouns form their accusatives in the manner of nouns: ö- $t, \ddot{o}-k e-t)$ :

$$
\begin{aligned}
& \text { accusative of } 1 \text { st/2nd person pronouns } \\
& \text { singular plural } \\
& \text { 1st engem(et) minket, bennünket } \\
& \text { 2nd téget(et) titeket, benneteket }
\end{aligned}
$$

The possessor suffixes $-m,-d,-n k$, -tek, can just about be discerned in these forms, which would make - $g$ - the 'accusative base' for non-3rd person singular pronouns and benn- the 'accusative base' for one of the plural form options. Note, however, that in the plural, and optionally in the singular, these forms include the accusative ending. Such double marking for case is found colloquially with other cases, too (e.g., along side nál-a-m 'with me’ we find nál-a-m-nál).

These pronominal forms pose very interesting questions for the formal description of Hungarian, though I have been unable to find explicit discussion of this issue. The problem is that the 1st, 2 nd person pronominals represent an unusual case of morphosyntactic mismatch. They fulfil the role of case marking with respect to pronouns, but the paradigms are defined in terms of the possessor agreement morphology of otherwise non-existent nouns. In a realizational model (e.g., Network Morphology, Corbett \& Fraser 1993, or Paradigm Function Morphology, Stump 2001) it would be possible in principle to account for this by means of a rule of referral, though there are difficulties in ensuring that a suffix can also be a noun stem. ${ }^{9}$ For present purposes I merely note that the grammar of Hungarian has to have some way of indicating that the feature set [Pronoun: $\{1 \mathrm{st}$, 2nd\}, [Case: $\mathrm{K}]$ ] is reinterpreted as the feature set [Lexeme- $\mathrm{K}$, [PossessorAgreement: $\{1$ st, $2 n d\}]$, where 'Lexeme- $K$ ' stands for the virtual case-noun base which gets inflected with possessor agreements. The question then arises whether the label [Case: $\mathrm{K}$ ] has to be the name of a genuine case attribute.

\section{Does Hungarian have a case system?}

I argued earlier that a canonical case system of the type found in inflectional languages such as Russian is one which must appeal to a morphosyntactic property, feature or attribute [Case] in order to generalize across systematically distinct

9. In Spencer (2006) I propose a rule of referral analysis within the framework of Generalized Paradigm Function Morphology, a generalization of Stump's (2001) model. 
forms. Clearly, whatever the Hungarian system represents it is not a canonical case system of that type. Is it necessary, therefore, to set up a [Case] attribute at all for the grammar of Hungarian, and if so what would it be used for?

Morphologically, we have found absolutely no need for such an attribute within the inflectional system of nouns and adjectives. There is no cumulation with any other property. When describing the 'case forms' of a noun, therefore, we only need to make reference to the ' $b a n$-form', or the ' $v a l$-form' or whatever, or use any other arbitrary labelling system (such as integers, as in the traditional Czech system, 'Form1, 2, ... 18'; cf. Comrie 1986, on the morphology of Russian case). Even the accusative personal pronouns don't give any reason to set up a case feature. The 3 rd person forms and the 1st, 2 nd plural forms can be treated as nouns with rather odd suppletive allomorphy in the case of the 1st, 2nd person forms, while the 1st, 2nd singular forms pattern like other cases, in exhibiting essentially a kind of possessor agreement over a suppleting 'case noun stem'. Admittedly, the 3rd person pronouns show rather odd behaviour in forming their accusatives as though they were nouns and their other cases as though they were pronouns, but this is orthogonal to the question of what kind of case attribute Hungarian may or may not have. Syntactically, there is no warrant for a case feature, whether on noun heads or on the right edge of noun phrases. The one apparent instance of case agreement is better thought of as an appositional construction.

The simple answer to the question, then, is that Hungarian nouns don't have a true case system. Rather, nouns bear inflectional markers which have the functions of adpositions in other languages, and which differ from the true postpositions of Hungarian only in relatively low-level morphological properties (and even then show fewer clear-cut differences than the cases/postpositions of many languages of a similar type). The cases, in other words, are better thought of as 'fused postpositions', a kind of regular portmanteau, akin to the portmanteau definite prepositional forms of German and Romance, such as German zum $=z u$ dem 'to the.M.Dat.sG' or French $d u=d e$ le 'of the.M.sG'. I return to the case forms of pronouns below.

On the morphological side the grammar needs to have a way of defining eighteen forms (provisionally labelled 'ban-form', ' $t$-form' and so on). On the syntactic side the grammar needs to relate these forms to various grammatical and lexical constructions. For instance, it is a (lexical) property of the ban-form that it conveys a meaning akin to that expressed by an English prepositional phrase headed by in. It is a (grammatical) property of the $t$-form that it realizes (usually!) the direct object of a transitive verb (much like a pe-phrase in Rumanian, the et-phrase of Hebrew, or the $a$-phrase of Spanish when the object is specific/animate). But there is no need to provide these forms with an additional label such as [Case: Accusative] any more than there is any need to provide English prepositional phrases such as 
of John with a label [Case: Genitive] (despite a long tradition in English and similar languages of doing exactly this!).

And yet to say that Hungarian lacks a case system is hardly an uncontroversial claim. Why should it be that linguistic descriptive tradition has taken Hungarian not only to illustrate a case system but to be a parade example of such a system? There are two reasons for this.

First, the case suffixes have the functions of cases in genuine case languages (for instance, in the languages which respect Beard's Criterion). But this does not make the suffixes into cases, any more than it would make English of into a genitive case. I have argued that there is a need to distinguish two notions of 'case' (cf. Comrie 1986), a morphological notion and a syntactic notion. I would argue that the term 'case' has also been used systematically with a third meaning, what we might call a 'metagrammatical usage' (see also Comrie 1986, fn. 11).

Languages have various ways of marking grammatical functions, including ways of marking dependents of predicates or of head nouns in noun phrases. These include adpositional words, adpositional clitics, edge inflections and head-marking affixes. Let's refer to such devices collectively as 'canonical GF markers on dependents' (CGFMDs). By this is meant 'the manner in which a canonical grammatical function (GF) such as SUBJECT, INDIRECT овJECT, etc. is marked on a dependent. CGFMDs show varying degrees of grammaticalization/morphologization, of course, and they may have other functions besides that of marking core grammatical functions. For instance, they may serve as 'semantic cases' (non-core adjuncts) or as discourse markers. Moreover, grammatical function markers on dependents may, non-canonically, mark other grammatical functions. This occurs when we have dative-marked subjects, genitive-marked objects, nominative-marked direct objects and so on.

Now, case labels such as nominative (object) or dative (subject) have come to be used whenever the canonical way of marking a subject is also used to mark certain objects, or whenever the canonical way of marking an indirect object is used to mark, say, the subject of an experiencer verb. But these patterns are independent of true case marking. Indeed, they are not necessarily a property of dependent marking in the first place. A verb which agrees with its indirect object may use the same agreement morphology to cross-reference an experiencer predicate subject even in a language which lacks the relevant case form, such as Abkhaz. Therefore, just because a morphosyntactic device, such as a set of suffixes, constitutes a prototypical set of CGFMDs, doesn't mean to say that this device deserves to be called a 'case system. On the contrary, by adopting such an analysis we would often do serious injustice to the grammar of the language.

This point is emphasized in Spencer \& Otoguro (2005) for Japanese. They show that the so-called 'case particles' have none of the properties of genuine cases 
(other than the metagrammatical property of being CGFMDs), and that they have a number of properties that genuine cases never have. Similarly, Spencer (2005) and Otoguro (2006) show in some detail that it is a grave error to think of the 'case particles' of Indo-Aryan languages such as Hindi as cases. Not only does this lead to the same conceptual confusion as with Japanese, it also makes it impossible to describe the real (admittedly somewhat vestigial) case system of these languages, in which attributive adjectives and demonstratives agree in number, gender and case with their head nouns (Hindi has three cases 'direct', 'oblique' and 'vocative'). In fact, the so-called case markers of Hindi are clitic postpositions, some of which are used to mark core grammatical functions.

A further problem with treating the clitic postpositions as cases is revealed when we look at the realization of direct objects in Hindi (or Turkish for that matter). Under certain circumstances (involving the usual properties of animacy, specificity, topicality and so on) a direct object can be marked with the clitic postposition ko. The canonical function of this postposition, however, is to mark the indirect object. Otherwise, a direct object is realized by noun phrase lacking any clitic postposition (the so-called 'nominative' form). Unfortunately, this form is the canonical way of realizing subjects in non-perfect tenses. (In the perfect tenses, the transitive subject is marked by an 'ergative' postposition ne, and intransitive subjects and direct objects are left unmarked.) There is, in fact, no dedicated marker for direct objects in any set of tenses. But this leads to complete confusion when we come to describe a sentence with an unmarked direct object, especially in the nonperfect tenses (where we can't have recourse to a description in terms of ergative/ absolutive marking). Is such a noun phrase 'in the nominative' but 'functioning as an accusative', or 'in the accusative' syntactically, but 'in the nominative' morphologically? Or is it in some kind of 'virtual' accusative case which is always syncretic with some other case (like the accusative of animate/inanimate masculines in Russian)? No way of finessing these questions leaves us with a sensible answer. Of course, if we abjure talk of 'cases' here there is no problem. There are various clitic postpositions, some of which have the function of expressing notions like 'subject of perfect tense form verb', 'specific, animate direct object' and so on. The default is to use no postposition. ${ }^{10}$

10. As for the Hindi 'genitive', which behaves like an adjectival modifier in agreeing with its head, the only way to make this into a case is to invent some convoluted story about 'Suffixaufnahme' even though what is really happening is that we have a particle which happens to agree like an adjective, rather like the 'associative $a$ ' marker of Bantu languages or the so-called 'genitive' clitic of Albanian (see Koptjevskaja-Tamm 2003: 660-665). 
The second motivation for the tradition of treating Hungarian as a prototypical case language is that Hungarian nominals obligatorily have special inflected forms for expressing case-related meanings. Therefore, the grammar of Hungarian has to appeal to some sort of feature to ensure that all nouns can get 'case' suffixes (and moreover, that they appear in the right order, after the plural and possessor suffixes).

In extant realizational theories of morphology the morphological organization is governed by an attribute or feature which applies to all nouns (better, to all nominals). Traditionally, this feature would take the form [Case: \{Nominative, Accusative, ... Inessive, ... \}]. However, these labels are for the linguist's convenience, they play no role in the grammar itself. All that the morphology needs is an attribute such as [Form: $\{t$-form, $\ldots$, , ban-form, $\ldots\}]$. Identifying these forms with 'cases' is then a metagrammatical description, with attendant advantages for typologizing, together with various pitfalls, as discussed above.

Notice that this [Form] feature is not actually a case feature and therefore there is no need to describe a form which is unmarked. This means that there is no nominative. Rather, the so-called nominative is simply the form that is used when there is no requirement to use a marked form. This can include a variety of situations, including possessive constructions and so-called 'noun incorporation' contexts. In (25) we see a bare noun form as a possessor, while in (26) we see essentially the same construction, in which the possessor corresponds to the direct object without accusative marking 'incorporated' into a nominalized verb:

(25) János könyv-e

János book-3sG.Poss

'János's book'

(26) a könyv elolvas-ás-a

the book read-NMLZR-3sG.poss

'the reading of the book'

Specifically, these bare forms are not 'genitives' (any more than -nek/nak 'datives' are 'genitives'!).

Hungarian provides just one apparent argument in support of a morphological [Case] feature. We have seen that the 'case' forms of pronominals are unusual in that take the possessor agreement form of an element which in some cases is homophonous to a case suffix. I know of no description of this alternation in a formal grammar of Hungarian but I have proposed that this unusual mode of exponence be handled by a rule of referral (Spencer 2006). The obvious way to state this rule is to use statements of the format 'for the [Case: $\mathrm{X}$ ] form of a pronoun with person/number features $\alpha$, take the [Case: X] suffix (or its suppletive variant) and inflect it as a possessed noun for features $\alpha^{\prime}$. However, it should be 
clear that all we really need is a feature which identifies specific forms of nominals. Whether we call that feature 'Case' or 'Form' is immaterial. The rule of referral can just as easily be stated as 'for the [Form: $\mathrm{X}$ ] form of a pronoun with person/ number features $\alpha$, take the [Form: X] suffix and inflect it as a possessed noun for features $\alpha$ '. To be sure there are interesting problems in defining the notion '[Form: $\mathrm{X}$ ] suffix' in a realizational theory (these are addressed in Spencer 2006), but these are independent of the question of whether a [Case] attribute is needed.

In sum, the Hungarian nominal system is similar to the English verbal system. The forms walking, walked of the lexeme walk defy sensible featural definition, because they are used in so many functions (walking, for instance can be analysed as a verb form, an adjective form or a noun). Although a variety of highly misleading traditional terms are entrenched for these forms ('present/past participle' and the like) the only motivated description is purely formal: [Form: -ing], [Form: -ed1],

[Form: -ed2], where [Form: -ed1], [Form: -ed2] are systematically identical except for a largish number of irregular verbs. Indeed, in a realizational approach to inflection this is precisely the situation we expect: affixes are not Saussurean signs, as they are in a classical morphemic model, and therefore there's no particular need for the morphological description to give any information about the typical meanings or functions of particular inflected forms.

Finally, there is one language which is structurally very similar to Hungarian in which it would be a positive disadvantage to insist on thinking of 'case suffixes' as genuine cases. Selkup (Kuznecova, Xelimskij and Gruškina, 1980) is a Samoyedic language (and hence at most distantly related to Hungarian) which happens to inflect nouns for number-possessor-case in essentially the same manner as Hungarian. Selkup nouns also take a very productive similitudinal suffix, -šal', creating an adjective with the meaning 'similar (in some contextually determined way) to N. What is interesting about this suffix is that it attaches to nouns inflected for number and/or possessor agreement even though its function seems to be that of a derivational, not an inflectional, affix (Kuznecova et al. 1980: 193):

$$
\begin{aligned}
& \text { mat pra-ny-šal' } \quad \text { qum } \\
& \text { I.GEN size-1sG-SIM.ADJ man } \\
& \text { 'man of my size (lit. man similar to my size)' }
\end{aligned}
$$

Moreover, it occupies the same position slot as the case markers and is in paradigmatic opposition to them (that is, it is incompatible with case markers). Although one could imagine meanings such as 'similar to with a knife (instrumental)' or 'similar to at the river (locative)' such forms are completely impossible, morphologically. Thus, although it is not itself a case suffix in any sense of the term, the -šal' suffix belongs functionally to the same set of suffixes as the case suffixes. 
What is important for Selkup morphology is not that there are case suffixes but that there is a position slot after the number and possessor markers for suffixes with 'case' and other functions. For Selkup, it would not only be unnecessary to define the elements occupying this slot with a [Case] attribute, it would be downright misleading.

\section{Some consequences}

If Hungarian lacks a case system then it doesn't matter how many 'cases' there are (just as it doesn't matter how many prepositions English has). This means that debate as to which suffixes are 'really' cases in Hungarian is really debate about something else. In part such debates centre around the criteria for labelling, not a very interesting question. The issues raised by Kiefer (1987) relate to more serious questions of regularity and productivity, as well as questions of word class assignment. The facts of languages like Hungarian show that some affixes can have partly or wholly adverbial functions and hence behave more like 'derivational' affixes than 'inflectional' ones. But this just makes Hungarian look a little like Selkup. However, all that really matters for the morphology is that (some) nouns bear such an affix, and that some affixes have restricted paradigms (for instance, they don't combine with already inflected forms). But this is a property of the [Form] attribute.

One of the problems posed by Hungarian cases that I haven't dwelt upon is the issue of whether we can call Hungarian cases properly 'inflectional'. In a language with truly inflectional cases like Russian all the cases have a least one set of purely grammatical uses and the question of whether a given case form can be used with a purely lexical meaning becomes secondary. Whether or not we imagine that, say, the instrumental case in Russian 'really' means 'by means of' and then has lots of additional uses, we also have to say that 'instrumental' is a value of the [Case] attribute in Russian. In Hungarian, where there is no motivation for a [Case] attribute as such, it becomes problematical when we find so many 'semantic cases' whose primary or only function is to express adverbial concepts such as 'from the surface of' or 'in the capacity of'. This looks very much as though we are changing the meaning of the base noun, adding a semantic predicate in order to obtain a new word (lexeme) which can be used as a kind of adverb. But if that is the situation, aren't we really talking about derivation rather than inflection?

To the extent that an inflection/derivation distinction can be maintained for any language, such a question turns out to be in any case irrelevant if Hungarian lacks a case system. The fact that some of the realizations of the [Form] attribute have clear-cut adverbial semantics is neither unexpected nor problematical, just 
as it is neither unexpected nor problematical that some English prepositions have purely grammatical uses, while others have purely semantic functions. Again, note that the Selkup similitudinal adjective suffix has some of the character of a derivational, not inflectional, suffix.

My conclusion, therefore, is that Hungarian nouns regularly and productively inflect for a [Form] feature which effectively defines a set of 'fused postpositional portmanteaus'. The best way of thinking of the labels for these forms is in terms of the forms themselves. There is no need to generalize over these forms by means of a redundant [Case] feature. Indeed, if we try to do that we encounter all sorts of conceptual conundrums which dissolve as soon as we realize that Hungarian doesn't actually have a case system.

\section{Abbreviations}

ACC - accusative, ADJ - adjectivizer, CGFMD - canonical grammatical function marker on dependents, DAT - dative, DEL - delative, GF - grammatical function, INESS - inessive, M - masculine, NMLZR - nominalizer, PL - plural, Poss possessor, SG - singular, SIM.ADJ - similitudinal adjective

\section{References}

Beard, R. 1995. Lexeme Morpheme Base Morphology. Stony Brook NY: SUNY Press.

Borin, L. 1986. Is Hungarian a case language? Fenno-ugrica suecana 8: 1-33.

Carstairs, A. 1987. Allomorphy in Inflexion. Beckenham: Croom Helm.

Comrie, B. 1986. On delimiting cases. In Case in Slavic, R.D. Brecht \& J.S. Levine (Eds), 86-106. Columbus OH: Slavica Publishers.

Comrie, B. \& Polinsky, M. 1998. The great Daghestanian case hoax. In Case, Typology and Grammar, A. Siewierska \& Jae Jung Song (Eds), 95-114. Amsterdam: John Benjamins.

Corbett, G.G. \& Fraser, N. 1993. Network morphology. Journal of Linguistics 29: 113-142.

Creissels, D. 2003. Suffixes casuels et postpositions en hongrois. Talk delivered to the conference Grammaire des formes faibles, Paris, 6 December, 2003. MS, University of Lyon 2.

Kenesei, I., Vágo, R.M. \& Fenyvesi, A. 1998. Hungarian. London: Routledge.

Kiefer, Ferenc. 1987. The cases of Hungarian nouns. Acta Linguistica Academiae Scientarum Hungaricae, Vol. 37: 93-101.

Kiefer, Ferenc. 2000. Strukturális magyar nyelvtan III: Morfológia. Budapest: Akadémiai Kiadó. Koptjevskaja-Tamm, M.S. 2003. Possessive noun phrases in the languages of Europe. In Plank (Ed.), 621-722.

Kuznecova, A.I., Xelimskij, E.A. \& Grushkina, E.V. 1980. Ocherki po sel'kupskomu jazyku. Moscow: Izdatel'stvo moskovskogo universiteta.

Moravcsik, E. 2003a. Inflectional morphology in the Hungarian noun phrase: A typological assessment. In Plank (Ed.), 113-252. 
Moravcsik, E. 2003b. Non-compositional definiteness marking in Hungarian noun phrases. In Plank (Ed.), 397-466.

Plank, F. 2003. Noun Phrase Structure in the Languages of Europe. Berlin: Mouton de Gruyter.

Otoguro, R. 2006. Morphosyntax of Case. A Theoretical Investigation of the Concept. Ph.D. dissertation, University of Essex.

Sadler, L. \& Spencer, A. 2001. Syntax as an exponent of morphological features. In Yearbook of Morphology 2000, G. Booij \& J. van Marle (Eds), 71-96. Dordrecht: Kluwer.

Selkirk, E.O. 1977. Some remarks on noun phrase structure. In Formal Syntax, P. Culicover, T. Wasow \& A. Akmajian (Eds), 285-316. New York NY: Academic Press.

Spencer, A. 2003. A realizational approach to case. In Proceedings of $L F G$ '03, T. Holloway King \& M. Butt (Eds). (Online: http://csli-publications.stanford.edu/LFG/08/lfg03.pdf)

Spencer, A. 2005. Case in Hindi. In Proceedings of LFG '05, M. Butt \& T. Holloway King (Eds), (Online: http://csli-publications.stanford.edu/LFG/10/lfg05.html)

Spencer, A. 2006. 'Heads' in generalized paradigm function morphology. Talk delivered to the 12th International Morphology Meeting, Budapest, 29 May 2006.

Spencer, A. \& Otoguro, R. 2005. Limits to case - a critical survey of the notion. In Competition and Variation in Natural Languages. The Case for Case, M. Amberber \& H. de Hoop (Eds), 119-145. Oxford: Elsevier.

Stump, G.T. 2001. Inflectional Morphology. A Theory of Paradigm Structure. Cambridge: CUP.

Tompa, J. 1985. Kleine Ungarische Grammatik. Budapest: Akadémiai Kiadó. 